\title{
Radium-223 Treatment in mCRPC Patient with Polycythemia Vera
}

\author{
Polisitemi Vera Tanılı mCRPC Hastasında Radyum-223 Tedavisi
}

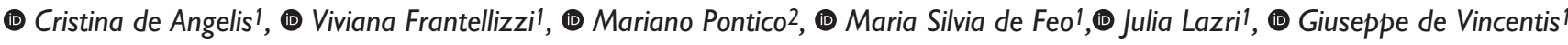 \\ ISapienza University of Rome, Department of Radiological Sciences, Oncology and Anatomical Pathology, Rome, Italy \\ 2Sapienza University of Rome, Ph.D. Program in Morphogenesis and Tissue Engineering, Department of Medico-surgical Sciences and \\ Biotechnologies, Rome, Italy
}

\begin{abstract}
There have been several studies on the clinical outcomes of Radium-223 treatment in patients with metastatic castration-resistant prostate cancer (mCRPC) who may have an increased risk of hematologic comorbidities. To the best of our knowledge, this is the first study to explore the potential bone marrow adverse effects (AEs) of Radium-223 administered with specific drugs used for hematologic conditions, such as polycythemia vera (PV). We report the case of a patient with $\mathrm{mCRPC}$ who was administered a combined treatment of Radium-223 and hydroxyurea for PV, aiming to support clinicians in predicting eventual AEs.

Keywords: Prostate cancer, mCRPC, Radium-223, polycythemia vera, hematogical toxicity
\end{abstract}

\section{Öz}

Hematolojik komorbidite riski artmış metastatik kastrasyona dirençli prostat kanseri (mCRPC) olan hastalarda Radyum-223 tedavisinin klinik sonuçları üzerine çeşitli çalışmalar yapıımıştır. Bilgimiz dahilinde bu çalışma, Radyum-223 ile birlikte polisitemia vera (PV) gibi bir hematolojik hastalık için özel ilaçlar alan bir hastada potansiyel kemik iliği yan etkilerinin (YE) araştırılıı̆ı ilk çalışmadır. Burada, klinisyenleri olası YE'leri öngörmede desteklemesi amaçlanan ve PV ile birlikte mCRPC tanısı için Radyum-223 ve hidroksiüre tedavileri uygulanan bir olgu sunulmuştur.

Anahtar Kelimeler: Prostat kanseri, mCRPC, Radyum-223, polisitemia vera, hematolojik toksisite

Prostate cancer $(\mathrm{PCa})$ represents the second most prevalent cancer in men and the fifth cause of cancerrelated mortality worldwide (1). Bone secondary tumor localizations are the most frequent expression of advanced $\mathrm{PCa}$, representing the cause of morbidity and mortality and determining a poor prognosis. Several studies have been provided concerning the clinical outcomes of Radium-223 treatment in patients with metastatic castration-resistant prostate cancer (mCRPC)
$(2,3)$. Moreover, patients with mCRPC could suffer from hematologic comorbidities. Notably, to our knowledge, there are no studies involving the use of Radium-223 in patients with $\mathrm{MCRPC}$ and preexisting hematological conditions, such as polycythemia vera (PV), a chronic myeloproliferative disorder. Thus, studies that could support clinicians to predict eventual adverse effects (AEs) in these cases are warranted.

Address for Correspondence: Mariano Pontico MD, Sapienza University of Rome, Ph.D. Program in Morphogenesis and Tissue Engineering, Department of Medico-surgical Sciences and Biotechnologies, Rome, Italy

Phone: 0649978590 E-mail: mariano.pontico@uniroma1.it ORCID ID: orcid.org/0000-0001-6143-4775

Received: 27.03.2020 Accepted: 05.08.2020 


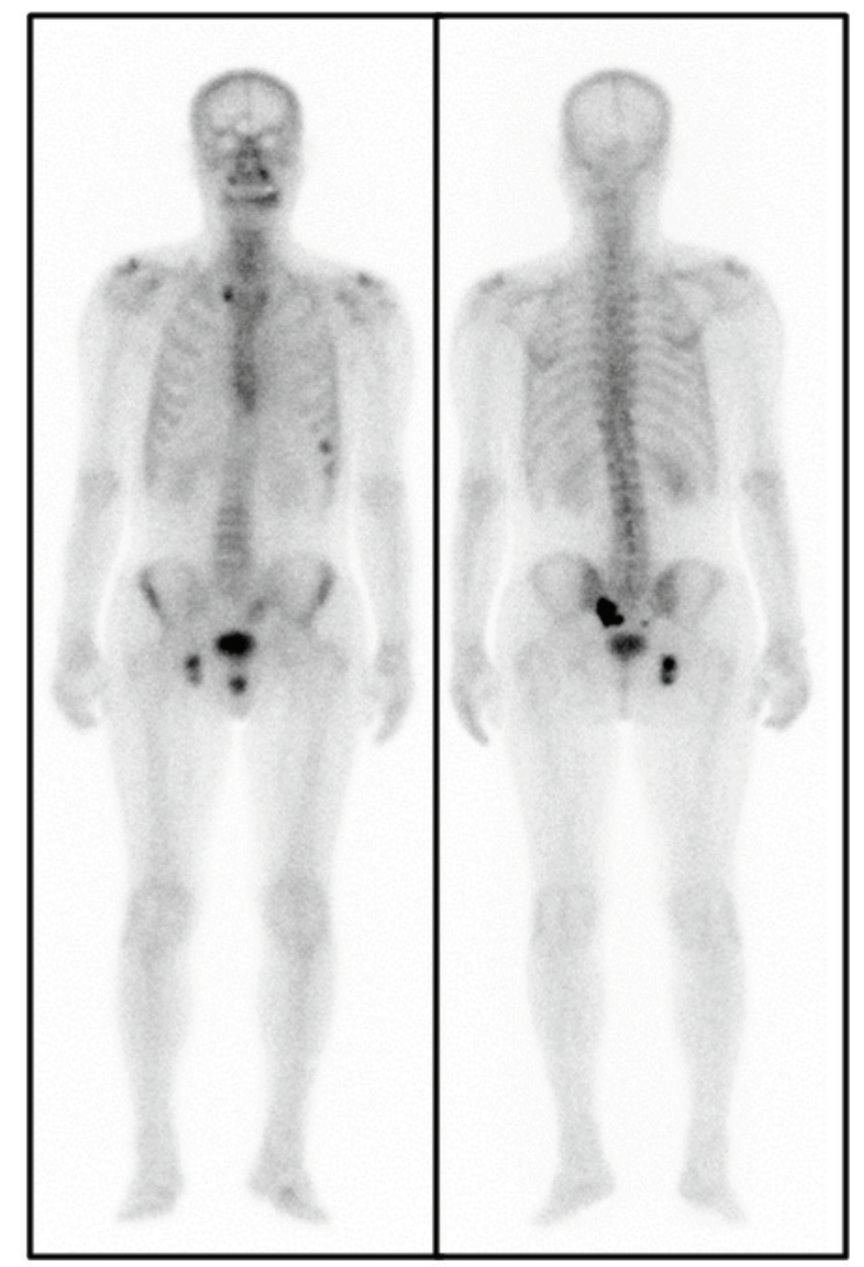

Figure 1. A 71-year-old male diagnosed with PV in 2000 and PCa in 2013 was referred to our hospital. After radical prostatectomy, the Gleason score was $8(3+5)$ with pT3b-R1 staging. In 2014, RT on the prostatic region was performed, and subsequently systemic treatment was introduced. Treatment with hydroxyurea for PV (500 mg for 5 days, 1000 mg for 2 days, per week) had also been administered. Radium-223 was administered according with the current EANM guidelines. Before the first administration, a technetium-99m -HDP bone scan was performed, depicting an oligometastatic disease. An interim bone scan was obtained after the third administration and a further one after the sixth at the end of treatment. Follow-up bone scans at 3,6 , and 12 months after the end of Radium-223 treatment was carried out.

Patients with $\mathrm{mCRPC}$ with compromised bone marrow reserve due to previous therapies have an increased risk of hematological AEs when enrolled in the Radium-223 treatment (4). Although the occurrence of anemia and neutropenia were not significantly different between placebo and the Radium-223 group in the ALSYMPCA trial (5), the cumulative effects of Radium-223 and other chemotherapies remain unelucidated.

In our case, no AEs of any kind were experienced during treatment. Hemoglobin ( $\mathrm{Hb}$ ) gradually reduced between the first and second cycles, but values remained $>13 \mathrm{mg} / \mathrm{dL}$. Consequently, the hematologist decided to lower the hydroxyurea dosage to $500 \mathrm{mg}$ once a day after the second cycle, and $\mathrm{Hb}$ values quickly normalized before the third administration. At the time of the first medical examination, the patient reported taking non-steroidal antiinflammatory drugs (NSAIDs) to control pain as necessary. Notably, after the first administration, the BPI value dropped from 5 to 0 , and NSAIDs were not required. One year after the first dose of Radium-223, the patient reported excellent control of bone pain and absence of the need for NSAIDs. 
a

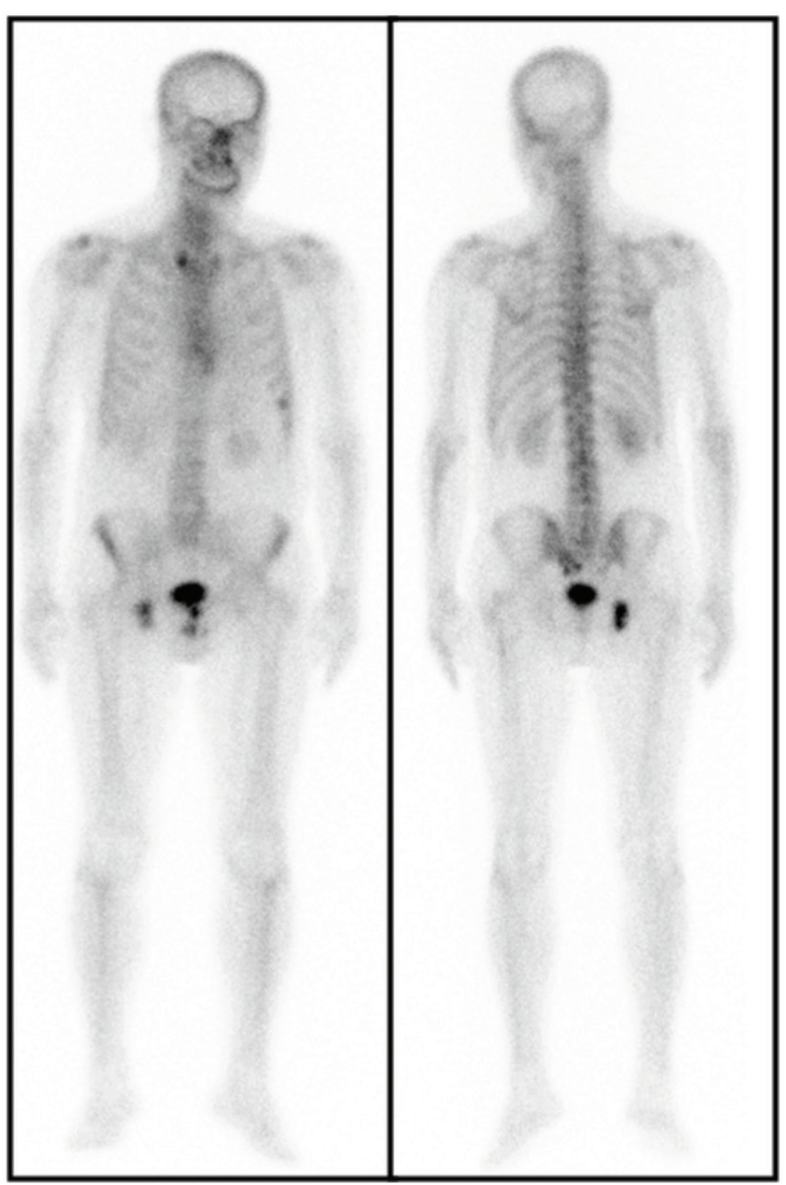

b

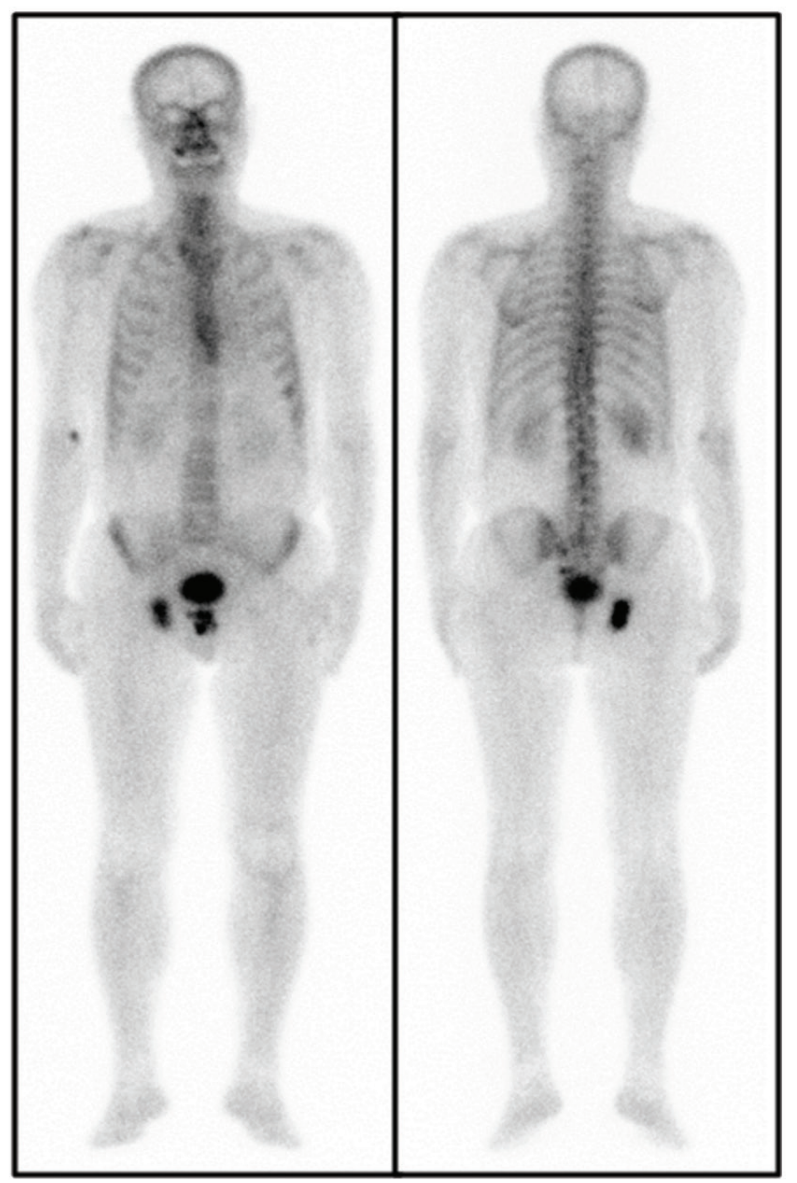

Figure 2. Compared to the pretreatment scan, the bone scan obtained after the conclusion of the Radium-223 treatment (a) revealed a marked regression of the osteotropic radiotracer increased uptake located in the right side of the sacrum, a significant reduction of uptake intensity of the same finding in the contralateral side, and a slighter decrease of uptake in the $7^{\text {th }}$ and $8^{\text {th }}$ left ribs. No differences were observed in the right ischiopubic ramus. Successively, a bone scan obtained 6 months after treatment showed total regression of the pathologic uptake located in the right side of the sacrum and an even more significant uptake intensity decline of the contralateral finding, such as that in the eighth left rib. No differences of radiotracer uptake were noted in the seventh left rib and in the right ischiopubic ramus. The bone scan obtained 1 year after Radium-223 administration (b) corroborated the favorable outcomes highlighted by the 6 months bone scan follow-up, confirming the persistence of osteotropic pathologic uptake in the $7^{\text {th }}$ left rib and in the right ischiopubic ramus with remnant weak increased uptake in the sacrum, suggesting a substantially stable disease. The benefits of Radium-223 in our patient with $\mathrm{mCRPC}$ were remarkable; not only did bone scans reveal a regression of skeletal secondary localizations uptake but pain control was also fairly obtained without using NSAIDs.

Several studies are investigating the effectiveness of a combination therapy on patients with $\mathrm{MCRPC}$ and its potential cumulative effect on hematologic toxicity. Even though the biological damages of Radium-223 on the bone marrow have been minimized $(6,7)$, defining the hematologic profile of patients with $\mathrm{mCRPC}$ is a key step to limit the chance of hematologic AEs. Although rare, the potential AEs of Radium-223 on bone marrow functionality must be considered (8). This has been the main concern when administering this radionuclide to patients with $\mathrm{mCRPC}$ who often receive or are still receiving other systemic therapies. Particular attention must be paid when MCRPC coexists with hematologic conditions that require suppression of the excessive functionality of the bone marrow. However, our study has several limitations, such as that PV may not represent the optimal model to assess the potential cytotoxic effects of hydroxyurea because PV is not typically characterized by the occurrence of a cytopenic condition.

This study supports and confirms the existing evidence in the literature about the hematologic safety of Radium-223 that is specifically applied in a patient with impaired bone marrow functionality due to PV. Additionally, Radium-223 appears to be safe and well tolerated even when combined with a cytotoxic agent, such as hydroxyurea. 


\section{Ethics}

Informed Consent: Informed consent was obtained from the patient.

Peer-review: Externally peer-reviewed.

\section{Authorship Contributions}

Surgical and Medical Practices: C.A., J.L., M.S.F, Concept: G.V., V.F., Design: G.V., V.F., M.P., Data Collection or Processing: V.F., C.A., Analysis or Interpretation: G.V., V.F, M.P., Literature Search: C.A., J.L., M.S.F., Writing: C.A., M.P., J.L.

Conflict of Interest: No conflict of interest was declared by the authors.

Financial Disclosure: The authors declared that this study received no financial support.

\section{References}

1. Wong MC, Goggins WB, Wang HH, Fung FD, Leung C, Wong SY, Ng CF, Sung JJ. Global Incidence and Mortality for Prostate Cancer: Analysis of Temporal Patterns and Trends in 36 Countries. Eur Urol 2016;70:862874.

2. Parker C, Nilsson S, Heinrich D, Helle SI, O'Sullivan JM, Fosså SD, Chodacki A, Wiechno P, Logue J, Seke M, Widmark A, Johannessen DC, Hoskin P, Bottomley D, James ND, Solberg A, Syndikus I, Kliment J, Wedel S, Boehmer S, Dall'Oglio M, Franzén L, Coleman R, Vogelzang NJ, O'Bryan-
Tear CG, Staudacher K, Garcia-Vargas J, Shan M, Bruland ØS, Sartor O; ALSYMPCA Investigators. Alpha emitter radium-223 and survival in metastatic prostate cancer. N Engl J Med 2013;369:213-223.

3. De Vincentis G, Follacchio GA, Frantellizzi V, Prelaj A, Farcomeni A, Giuli A, Bianco V, Tomao S. 223Ra-dichloride therapy in an elderly bone metastatic castration-resistant prostate cancer patient: a case report presentation and comparison with existing literature. Aging Clin Exp Res 2018;30:677-680

4. Ricci M, Frantellizzi V, Bulzonetti N, De Vincentis G. Reversibility of castration resistance status after Radium-223 dichloride treatment: clinical evidence and review of the literature. Int J Radiat Biol 2019;95:554-561.

5. De Vincentis G, Monari F, Baldari S, Salgarello M, Frantellizzi V, Salvi E, Reale L, Napolitano S, Conti G, Cortesi E. Narrative medicine in metastatic prostate cancer reveals ways to improve patient awareness \& quality of care. Future Oncol 2018;14:2821-2832.

6. Vogelzang NJ, Coleman RE, Michalski JM, Nilsson S, O'Sullivan JM, Parker C, Widmark A, Thuresson M, Xu L, Germino J, Sartor O. Hematologic Safety of Radium-223 Dichloride: Baseline Prognostic Factors Associated With Myelosuppression in the ALSYMPCA Trial. Clin Genitourin Cancer 2017;15:42-52.e8.

7. Saad F, Carles J, Gillessen S, Heidenreich A, Heinrich D, Gratt J, Lévy J, Miller K, Nilsson S, Petrenciuc O, Tucci M, Wirth M, Federhofer J, O'Sullivan JM; Radium-223 International Early Access Program Investigators. Radium-223 and concomitant therapies in patients with metastatic castration-resistant prostate cancer: an international, early access, openlabel, single-arm phase 3b trial. Lancet Oncol 2016;17:1306-1316.

8. De Vincentis G, Follacchio GA, Frantellizzi V, Liberatore M, Monteleone F, Cortesi E. Prostate-Specific Antigen Flare Phenomenon During 223RaDichloride Treatment for Bone Metastatic Castration-Resistant Prostate Cancer: A Case Report. Clin Genitourin Cancer 2016;14:e529-e533. 